\title{
Faktor-faktor yang Mempengaruhi Opini Audit Going Concern terhadap Nilai Keuangan Perusahaan Manufaktur Consumer Goods Industry
}

\author{
Julianty Fortuna ${ }^{1}$, Silviana ${ }^{2}$, Christian Jerriko ${ }^{3}$, Tetty Tiurma Uli Sipahutar ${ }^{4 *}$ \\ 1,2,3,4) Universitas Prima Indonesia \\ fortunaajulianty@gmail.com, nanaaozora02@gmail.com, sterbenn2505@gmail.com, \\ ratuhapis.tetty@gmail.com
}

*Penulis Korespondensi

Diajukan : 23 Juni 2021

Disetujui : 28 Juli 2021

Dipublikasi : 5 Agustus 2021

\begin{abstract}
The purpose of this research was held to test and analyze how the influence of company size, liquidity, profitability and capital structure on the value of the company through the opinion of audit going concern as an intervening variable. The number of populations used in the consumer goods sector is 61 companies, with purposive sampling techniques obtained research samples as many as 23 companies with a research period of 5 years (2015-2019). This data processing technique uses 2 techniques, namely multiple and logistics. The test results showed the company's size, liquidity, capital structure and audit opinion going concern did not affect the value of the company's consumer goods, profitability positively and significantly affected the value of the company. While the variables that affect the opinion of the audit going concern is liquidity and capital structure with a positive and significant influence while the size of the company and profitability does not affect the opinion of the audit going concernnya. Indirect test results of company size and liquidity through audit opinion going concern have an influence on the value of the company while indirectly profitability and capital structure through audit opinion going concern has no influence on the value of the company.
\end{abstract}

Keywords: Liquidity ; Company Value ; Audit Opinion Going Concern ; Profitability ; Capital Structure ; Company Size.

\section{Latar Belakang Masalah}

\section{PENDAHULUAN}

Perusahaan yang berkembang di era globalisasi masa sekarang ini banyak memancing para investor untuk mendanai perusahaannya sehingga muncul para pesaing bisnis yang semakin ketat dimana perusahaan harus mampu untuk bersaing dalam bidang konsumsi. Hal ini dapat di lihat dari permintaan masyarakat, serta banyak yang tertarik mendirikan bisnis dalam perusahaan sektor konsumsi barang di Indonesia.

Masalah Opini Audit Going Concern dinyatakan oleh seorang auditor sebagai tolak ukur untuk menentukan adanya status Opini Audit Going Concern yang berdampak pada reputasi perusahaan serta mengakibatkan turunnya harga saham,sulitnya mengajukan pinjaman kepada kreditor dan investor,karyawan maupun pelanggan (Dewayanto, 2011). Berdasarkan fenomena yang diambil peneliti setelah membaca harian berita bisnis, PT Tiga Pilar Sejahtera Food Tbk (AISA) yang telah terancam perdagangannya dikarenakan kasus anak perusahaan pertengahan Juni 2017 yang diduga melakukan pemalsuan dengan memproduksi beras yang merupakan tanaman subsidi pemerintah yang menghasilkan beras medium selanjutnya dijual dengan harga beras premium. Auditor menyatakan tidak memperoleh bukti audit yang cukup tepat atas saldo perubahan akun piutang lain-lain non usaha yang disajikan pada pos lain-lain yang pada tanggal 31 Desember 2019 dicatat sebesar Rp326,66 miliar serta saldo dan transaksi akun liabilitas keuangan jangka pendek lainnya 
yang disajikan pada pos lain-lain yang pada akhir tahun lalu dicatat sebesar Rp30,64 miliar. Auditor independen yang telah melakukan audit atas laporan keuangan konsolidasian perseroan dan entitas anak usaha untuk tahun yang berakhir pada tanggal 31 Desember 2019 menyatakan telah memberikan opini 'Wajar Dengan Pengecualian'.

Nilai perusahaan sebagai suatu harga yang harus bersedia dibayar oleh calon investor seandainya apabila suatu perusahaan tersebut akan dijual dimana mer dari nilai pasar, karena nilai perusahaan dapat memberikan kemakmuran pemegang saham secara maksimum apabila harga saham perusahaan meningkat (Wardhani, 2013). Beberapa faktor yang dapat mempengaruhi harga nilai suatu perusahaan yakni Ukuran perusahaan, Likuiditas, Profitabilitas, dan Struktur modal. Penelitian Terdahulu (Nugroho, 2018) yang berjudul "Faktor-Faktor Yang Mempengaruhi Opini Audit Going Concern" menunjukan bahwa Profitabilitas, Likuiditas dan ukuran perusahaan berpengaruh negatif terhadap Opini audit Going Concern dan Leverage berpengaruh positif terhadap Opini Going Concern periode 2012-2016. Ukuran perusahaan dikategorikan sebagai suatu gambaran pada perusahaan besar ataupun kecil yang dapat dilihat melalui total aset, penjualan bersih maupun kapitalisasi pasar (Nugroho, 2018). Sebelum berinvestasi, para investor akan melihat performa perusahaan seperti Likuiditas dan profitabilitas perusahaan (Sitorus, 2017). Apabila suatu perusahaan memiliki tingkat likuiditas yang baik maka para investor dapat tertarik untuk menanamkan modalnya pada perusahaan (Khairunnisa, 2018). Nilai perusahaan dapat pula dipengaruhi oleh besar kecilnya profitabilitas yang dihasilkan oleh perusahaan (Analisa, 2011). Nilai perusahaan dapat dipengaruhi oleh Debt to Total Asset dalam membiayai operasional dan investasi perusahaan tidak selalu memliki dana yang cukup untuk memenuhi kebutuhan dan anggaran yang telah ditetapkan (Jimenez, 2015).

\section{Penelitian Terdahulu}

\section{STUDI LITERATUR}

\section{Teori Pengaruh Ukuran Perusahaan (Firm Size) Terhadap Nilai Perusahaan}

Ukuran perusahaan dianggap mempengaruhi nilai perusahaan karena semakin besar ukuran perusahaan maka semakin mudah perusahaan memperoleh sumber pendanaan yang dapat dimanfaatkan untuk mencapai tujuan perusahaan. Menurut (Indriyani, 2017), di sisi lain akan menimbulkan hutang yang banyak karena resiko perusahaan dalam memenuhi tanggung jawabnya sangat kecil.

\section{Teori Pengaruh Likuiditas Terhadap Nilai Perusahaan}

Likuiditas merupakan kemampuan perusahaan untuk memenuhi kewajiban jangka pendeknya.Semakin tinggi rasio maka semakin tinggi pula kemampuan perusahaan untuk memenuhi kewajibannya. Selain itu tingginya rasio likuiditas menggambarkan ketersediaan dana perusahaan untuk melakukan operasi perusahaan dan membayarkan dividen.Perusahaan yang memiliki tingkat likuiditas yang tinggi tentunya dianggap menjadi prospek yang bagus oleh para investor, karena para investor mempersepsikan perusahaan memiliki kinerja yang baik sehingga bisa meningkatkan harga saham yang berarti nilai perusahaan juga meningkat (Putra \& Lestari, $\underline{2016})$.

\section{Teori Pengaruh Profitabilitas Terhadap Nilai Perusahaan}

Menurut (Mardiyati, 2012), semakin tinggi nilai profit yang didapat maka akan semakin tinggi nilai perusahaan. Hal ini terjadi akibat profit yang tinggi akan memberikan indikasi prospek perusahaan yang baik sehigga dapat memicu investor untuk ikut meningkatkan permintaan saham. Permintaan saham yang meningkat akan menyebabkan nilai perusahaan yang meningkat.

\section{Teori Pengaruh Struktur Modal (Debt Ratio) Terhadap Nilai Perusahaan}

Struktur Modal (Debt Ratio) termasuk ratio Solvabilitas yang berhubungan dengan pendanaan hutang dengan menentukan presentase aktiva yang di dukung oleh hutang. Rasio ini berpengaruh terhadap nilai perusahaan karena investor akan memilih nilai DTA yang tinggi karena menunjukan tingkat resiko keuangan yang akan ditanggung oleh perusahaan (Jimenez, 2015). 


\section{Teori Pengaruh Ukuran Perusahaan (Firm Size) Terhadap Opini Audit Going Concern}

Apabila semakin tinggi total aset yang dimiliki oleh suatu perusahaan maka dianggap perusahaan tersebut memiliki kelangsungan hidup perusahaannya dan memiliki peluang besar untuk tidak mengalami Opini Audit Going Concern. Menurut (Alichia, 2013), perusahaan memiliki probabilitas lebih besar untuk memenangkan persaingan atau bertahan dalam industri. Indicator yang dapat digunakan Ukuran perusahaan terhadap Opini Audit Going Concern adalah Total Asset.

$$
\text { Ukuran Perusahaan }=\operatorname{Ln} \frac{\text { total aktiva }}{\text { total aset }}
$$

\section{Teori pengaruh Likuditas terhadap Opini Audit Going Concern}

Apabila perusahaan dinyatakan mampu untuk melunasi kewajibannya maka perusahaan dapat dinyatakan tidak berpeluang besar memiliki Opini Audit Going Concern dan sebaliknya. Menurut (Rahman \& Ahmad, 2018), Likuiditas sebagai kemampuan perusahaan dalam membayar kewajiban kepada kreditor dan apabila perusahaan semakin kecil likuidnya maka auditor akan memungkinkan mengeluarkan pendapat Opini Audit Going Concern. Indicator yang dapat digunakan pada variable ini adalah Quick Ratio.

$$
\text { Current ratio }=\frac{\text { Current assets }}{\text { Current Liabilities }}
$$

\section{Teori pengaruh Profitabilitas terhadap Opini Audit Going Concern}

Rendahnya profitabilitas sebuah perusahaan, maka semakin rendah kemampuan perusahaan untuk menghasilkan laba yang dapat mengakibatkan keraguan auditor untuk memberikan Opini Going Concern. Menurut (Rakatenda \& Putra, 2016), bahwa semakin besar nilai ROA maka tidak menimbulkan auditor untuk mengeluarkan Opini Audit Going Concern. Indicator yang digunakan variable ini adalah ROA (Return on Asset).

$$
\text { Return On Assets }=\frac{\text { Net Profit }}{\text { Total Asset }}
$$

\section{Teori Pengaruh Struktur Modal Terhadap Opini Audit Going Concern}

Menurut (Minerva et al., 2020), Debt Ratio dapat menggambarkan total hutang yang dibandingkan dengan total aset pada perusahaan. Semakin tinggi nilai DTA (Debt to Total Asset) maka semakin tinggi penerimaan menghasilkan Opini Audit Going Concern. Indicator yang digunakan untuk variable ini adalah Debt Ratio.

$$
\text { Debt Ratio }=\frac{\text { Total Debt }}{\text { Total Asset }}
$$

\section{Kerangka Konseptual}

Berdasarkan uraian di atas,sehingga dapat diperoleh gambar kerangka konspetual sebagai berikut:

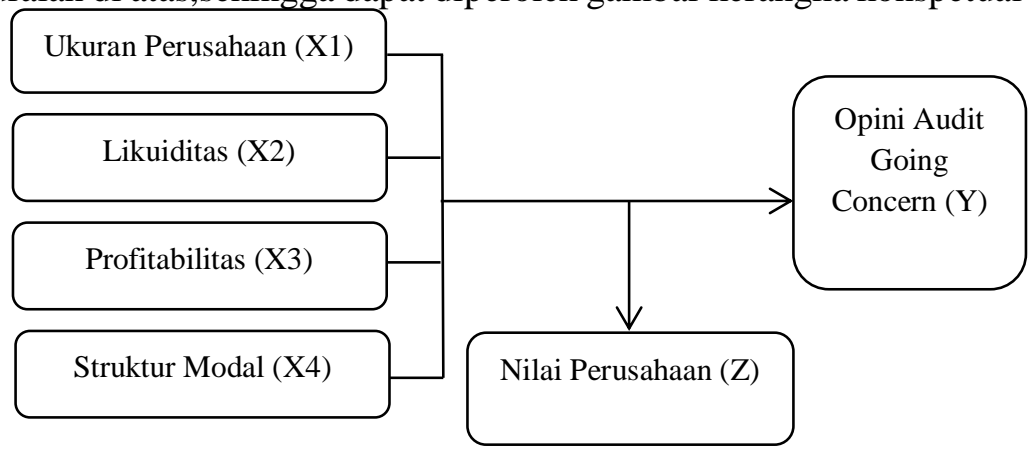

Gambar 2.9 Kerangka Konseptual

METODE

Penelitian dilakukan pada perusahaan manufaktur Consumer Goods yang telah terdaftar dan dipublikasikan di BEI melalui website. www.idx.co.id dan situs resmi perusahaan. Jenis penelitian 
yang dilakukan berupa penelitian kuantitatif yang bersifat deskriptif. Jumlah populasi dalam penelitian ini terdapat 61 perusahaan manufaktur Consumer Goods Industry. Sampel yang digunakan dalam penelitian ini telah dipilih melalui metode purposive sampling yang bertujuan untuk memastikan bahwa data laporan keuangan yang dihasilkan populasi tersebut sesuai dengan tujuan penelitan. Sampel penelitian ada 23 perusahaan, dengan mengambil 5 tahun penelitian sehingga $23 \times 5=115$ Perusahaan Consumer Goods Industry.

\section{Model Penelitian}

Teknik analisa data yang digunakan dalam penelitian ini adalah analisis regresi linear berganda dan longistik dengan menggunakan SPSS (Statistical Product and Service Solution).

$\mathrm{Y}=\alpha+\beta 1 \mathrm{X} 1+\beta 2 \mathrm{X} 2+\beta 3 \mathrm{X} 3+\beta 4 \mathrm{X} 4+\varepsilon$

$\mathrm{Z}=\alpha+\beta 1 \mathrm{X} 1+\beta 2 \mathrm{X} 2+\beta 3 \mathrm{X} 3+\beta 4 \mathrm{X} 4+\beta 5 \mathrm{Y}+\varepsilon$

$\mathrm{X} 1$ : Ukuran Perusahaan

$\mathrm{X} 2$ : Likuiditas

X3 : Profitabilitas

X4 : Struktur Modal

$\beta \quad$ : Koefisien Regresi

$\alpha \quad$ : Konstanta Regresi

$\mathrm{Z} \quad$ : Nilai Perusahaan

Y : Opini Audit Going Concern

\section{Statistik Deskriptif}

HASIL

Uji ini untuk menunjukkan gambaran data minimum, maksimum dan mean dari masingmasing variabelnya.

Tabel 4.1. Statistik Deskriptif

\begin{tabular}{|c|c|r|r|r|r|}
\hline & $\mathrm{N}$ & Minimum & Maximum & \multicolumn{1}{c|}{ Mean } & Std.Deviation \\
\hline Ukuran Perusahaan & 115 & 11.576 & 32.201 & 21.34897 & 8.508836 \\
\hline Likuiditas & 115 & .488 & 8.632 & 2.31597 & 1.656840 \\
\hline Profitabilitas & 115 & .001 & .921 & .13349 & .124391 \\
\hline Struktur Modal & 115 & .071 & .744 & .35590 & .175336 \\
\hline Nilai Perusahaan & 115 & .295 & 82.444 & 5.85042 & 12.576304 \\
\hline OpiniGoingConcern & 115 & 0 & 1 & .27 & .446 \\
\hline Valid N (listwise) & 115 & & & & \\
\hline
\end{tabular}

Tabel di atas memperlihatkan :

1. Ukuran perusahaan minimumnya pada PT. Sekar Laut, tbk tahun 2015 yaitu 11,576 sedangkan maksimumnya pada PT. Indofood Sukses Makmur, Tbk tahun 2018 yaitu 32,201.

2. Likuiditas, minimumnya pada PT. Tunas Baru Lampung, tbk tahun 2015 yaitu 0,488 sedangkan maksimumnya pada PT. Jamu Sidomuncul, tbk tahun 2015 yaitu 8,632

3. Profitabilitas, minimumnya pada PT. Sekar Laut, tbk tahun 2016 yaitu 0,001 sedangkan maksimumnya pada PT. Merck, tbk tahun 2018 yaitu 0,921.

4. Struktur modal, minimumnya pada PT. Jamu Sidomuncul, tbk tahun 2015 yaitu 0,071 sedangkan maksimumnya pada PT. Unilever, tbk 2019 yaitu $0,744$.

5. Nilai perusahaan, minimumnya pada PT Wismilak tahun 2018 yaitu 0,295 sedangkan maksimumnya pada PT. Unilever tahun 2017 yaitu 82,444.

6. Nilai rata-rata opini going concern sebesar 0,27 menunjukkan bahwa sektor consumer goods rata-rata mendapat pendapat wajar tanpa pengecualian.

\section{Hasil Uji Asumsi Klasik Model I}


Model I yang akan diuji adalah model regresi ukuran perusahaan, likuiditas, profitabilitas, struktur modal dan opini going concern terhadap nilai perusahaannya. Berikut ini hasil uji asumsi klasiknya setelah data ditransformasi:

\section{Hasil Uji Normalitas}

\section{Tabel 4.2. Hasil Uji Kolmogorov Smirnov Setelah Transformasi} One-Sample Kolmogrov-Smirnov Test

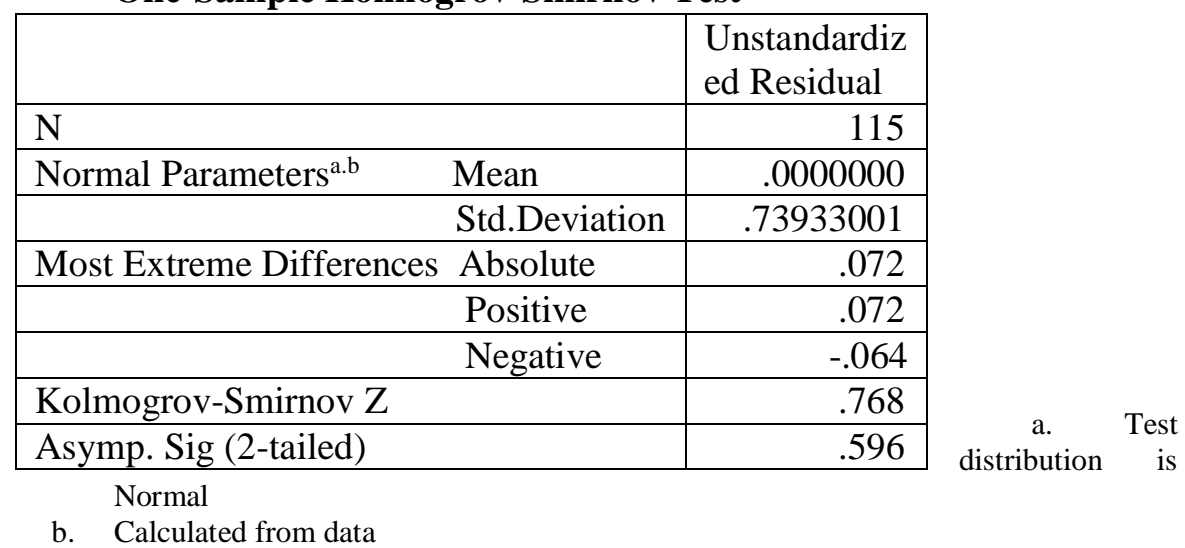

Signifikan hasil uji tersebut 0,596 memperlihatkan jika data model regresi pertama memiliki data yang berdistribusi secara normal.

\section{Hasil Uji Multikolineritas}

Adapun hasil uji ini baik sebelum dan setelah transformasi data memperlihatkan tidak terjadi korelasi diantara variabel independen yang dimasukan.

Tabel 4.2.2 Hasil Uji Multikolinearitas

\begin{tabular}{|ll|r|c|}
\hline & & Collinearity & Statistics \\
\hline Model & & Tolerance & VIF \\
\hline 1 & LN_UkuranPerusahaan & .936 & 1.069 \\
\hline & LN_Likuiditas & .111 & 9.016 \\
\hline & LN_Profitabilitas & .912 & 1.097 \\
\hline & LN_StrukturModal & .114 & 8.751 \\
\hline & OpiniGoingConcern & .964 & 1.037 \\
\hline
\end{tabular}

a. Dependent Variable : LN_NilaiPerusahaan

Masing-masing tolerance dan VIF sudah > 0,10 dan lebih kecil dari 10 memperlihatkan tidak mengalami multikolinearitas.

\section{Hasil Uji Autokorelasi}

Teknik yang dipilih untuk mengetahui ada tidaknya korelasi pada model regresi ini yaitu menggunakan run test dikarenakan tidak terpenuhinya uji menggunakan pedoman durbin-watson

Tabel 4.2.3 Hasil Uji Run Test

\begin{tabular}{|l|r|}
\hline & Unstandardiz ed Residual \\
\hline Test Value $^{\mathrm{a}}$ & $2.18990^{\mathrm{b}}$ \\
\hline Cases $<$ Test Value & 114 \\
\hline Cases $>=$ Test Value & 1 \\
\hline Total Cases & 115 \\
\hline Number of Runs & 3 \\
\hline $\mathrm{Z}$ & .133 \\
\hline
\end{tabular}


Owner: Riset \& Jurnal Akuntansi

e-ISSN : 2548-9224 |p-ISSN : 2548-7507

Volume 5 Nomor 2, Agustus 2021

DOI : https://doi.org/10.33395/owner.v5i2.477

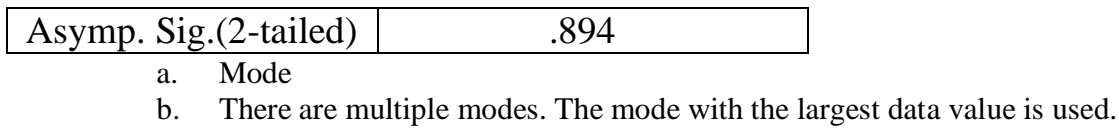

Nilai ini sebesar 0,894 memperlihatkan tidak terjadi autokorelasi.

\section{Hasil Uji Heteroskedastisitas}

Model regresi yang baik harusnya tidak terjadi heteroskedastisitas, adapun pada model regresi ini hasil ujinya yaitu :

\section{Tabel 4.2.4 Hasil Uji Park}

Coefficients $^{\mathrm{a}}$

\begin{tabular}{|c|c|c|c|c|c|}
\hline \multirow[b]{2}{*}{ Model } & \multicolumn{2}{|c|}{ Unstandardized Coefficients } & \multirow{2}{*}{$\begin{array}{l}\text { Stand. } \\
\text { Coefficients } \\
\text { Beta }\end{array}$} & \multirow[b]{2}{*}{$\mathrm{t}$} & \multirow[b]{2}{*}{ Sig } \\
\hline & B & Std. Error & & & \\
\hline \multirow[t]{2}{*}{1 (Constant) } & -2.207 & 1.582 & & - & \\
\hline & & & & 1.395 & .168 \\
\hline LN_Ukuran Perusahaan & .611 & 412 & .202 & 1.483 & .143 \\
\hline LN_Likuiditas & -.058 & .763 & -.034 & $\begin{array}{c}- \\
.076\end{array}$ & .939 \\
\hline LN_Profitabilitas & -.005 & .159 & -.004 &. & .976 \\
\hline \multirow[t]{2}{*}{ LN_StrukturModal } & .163 & .955 & .074 & .170 & .865 \\
\hline & .467 & .395 & .151 & 1.182 & .242 \\
\hline
\end{tabular}

a. Dependent Variable : LnU2i

Signifikansinya untuk masing-masing variabel mengindikasikan jika model regresi ini sudah terbebas dari masalah heteroskedastisitas.

\section{Hasil Uji Regresi Logistik Model II \\ Hasil Uji Model Fit}

Uji ini digunakan untuk menilai ketepatan fungsi regresi dalam menaksir nilai aktualnya.

Tabel 4.3 Uji Hosmer Lemeshow

\begin{tabular}{|l|c|c|c|}
\hline Step & Chi-Square & df & Sig. \\
\hline 1 & 12.011 & 8 & .151 \\
\hline
\end{tabular}

Model regresi ini dikatakan fit dengan data aktualnya karena signifikansi 0,151 yang lebih tinggi dari 0,05 .

\section{Uji Kelayakan Model Regresi}

Uji ini dilihat dengan nilai beginning block dan akhirnya.

Tabel 4.3 Uji -2 LL Awal

\begin{tabular}{|c|c|c|}
\hline & $-2 \log$ & Coefficients \\
\hline Iteration & likelihood & Constant \\
\hline Step 0 & 134.179 & -.922 \\
\hline 2 & 134.050 & -.996 \\
\hline 3 & 134.050 & -.997 \\
\hline 4 & 134.050 & -.997 \\
\hline & & \\
\hline
\end{tabular}


Owner: Riset \& Jurnal Akuntansi

e-ISSN : 2548-9224 |p-ISSN : 2548-7507

Volume 5 Nomor 2, Agustus 2021

DOI : https://doi.org/10.33395/owner.v5i2.477

a. Constant is included in the model.

b. Initial -2 Log Likelihood : 134.050

c. Estimation terminated at iteration number 4 because parameter estimates changed by less than .001

Tabel 4.3 Uji -2LL Akhir

Iteration History $\mathbf{a}, \mathrm{b}, \mathrm{c}, \mathrm{d}$

\begin{tabular}{|c|c|c|c|c|c|c|}
\hline \multirow[b]{2}{*}{ Iteration } & \multirow{2}{*}{$\begin{array}{c}-2 \log \\
\text { likelihood }\end{array}$} & \multicolumn{5}{|c|}{ Coefficients } \\
\hline & & Constant & $\begin{array}{c}\text { Ukuran } \\
\text { Perusahaan }\end{array}$ & Likuiditas & Profitabilitas & $\begin{array}{c}\text { Struktur } \\
\text { Modal }\end{array}$ \\
\hline Step 1 & 121.291 & -3.683 & -.021 & .606 & -.718 & 5.322 \\
\hline 2 & 120.242 & -4.464 & \begin{tabular}{|l|}
-028 \\
\end{tabular} & .753 & -.854 & 6.602 \\
\hline 3 & 120.233 & -4.538 & -.029 & .770 & -.869 & 6.731 \\
\hline 4 & 120.233 & -4.539 & -.029 & .770 & -.869 & 6.732 \\
\hline 5 & 120.233 & -4.539 & -.029 & .770 & -.869 & 6.732 \\
\hline
\end{tabular}

a. Method : Enter

b. Constant is included in the model

c. Initial -2 Log Likelihood 134.050

d. Estimation terminated at iteration number 5 because parameter estimates changed by less than .001 .

Pengurangan nilai -2LL awal (pada blok 0) dengan nilai -2LL akhir (pada blok 1) menunjukkan bahwa model yang dihipotesiskan fit dengan data. Penurunan likelihood (-2LL) ini menunjukkan model regresi yang lebih baik atau dengan kata lain model yang dihipotesiskan fit dengan data.

\section{Hasil Uji Hipotesis}

Model Regresi I

Hasil Uji Secara Parsial

\section{Tabel 4.4 Hasil Uji t \\ Coefficients $^{\mathrm{a}}$}

\begin{tabular}{|c|c|c|c|c|c|}
\hline \multirow[b]{2}{*}{ Model } & \multicolumn{2}{|c|}{$\begin{array}{l}\text { Unstandardized } \\
\text { Coefficients }\end{array}$} & \multirow{2}{*}{$\begin{array}{l}\text { Stand. } \\
\text { Coefficients } \\
\text { Beta }\end{array}$} & \multirow[b]{2}{*}{$\mathrm{t}$} & \multirow[b]{2}{*}{ Sig. } \\
\hline & B & Std. Error & & & \\
\hline 1 (Constant) & 3.894 & .668 & & 5.832 & 000 \\
\hline LN_Ukuran Perusahaan & -.193 & .172 & -.080 & $\begin{array}{l}- \\
1.121\end{array}$ & .265 \\
\hline LN_Likuiditas & -.154 & .299 & -.107 & $\begin{array}{l}- \\
.514\end{array}$ & .609 \\
\hline LN_Profitabilitas & .753 & .078 & .697 & 9.601 & .000 \\
\hline LN_StrukturModal & .321 & .391 & .168 & .821 & .413 \\
\hline OpiniGoingConcern & -.187 & .162 & -.081 & $\overline{-} 1.155$ & .251 \\
\hline
\end{tabular}

a. Dependent Variable : LN_NilaiPerusahaan

Hasil yang didapat secara parsial yaitu :

1. $-\mathrm{t}$ hitung $-1,121>-\mathrm{t}$ tabel $-1,98197=\mathrm{H} 0$ diterima : Ukuran perusahaan tidak berpengaruh terhadap nilai perusahaan 
2. $-\mathrm{t}$ hitung $-0,514>-\mathrm{t}$ tabel $-1,98197=\mathrm{H} 0$ diterima : current ratio tidak berpengaruh terhadap nilai perusahaan

3. $\mathrm{t}$ hitung 9,601 > t tabel $1,98197=$ Ha diterima : ROA berpengaruh positif terhadap nilai perusahaan

4. $\mathrm{t}$ hitung $0,821<\mathrm{t}$ tabel $1,98197=\mathrm{H} 0$ diterima : debt ratio tidak berpengaruh terhadap nilai perusahaan

5. $-\mathrm{t}$ hitung $-1,155>-\mathrm{t}$ tabel $-1,98197=\mathrm{H} 0$ diterima : opini going concern tidak berpengaruh terhadap nilai perusahaan

\section{Hasil Uji Secara Simultan}

Tabel 4.4.2 Hasil Uji F

ANOVA

\begin{tabular}{|ll|r|r|r|r|r|}
\hline Model & $\begin{array}{c}\text { Sum of } \\
\text { Squares }\end{array}$ & df & Mean Square & F & Sig. \\
\hline 1 & Regression & 56.768 & 5 & 11.354 & 19.860 & $.000^{\mathrm{b}}$ \\
\hline & Residual & 62.313 & 109 & .572 & & \\
\hline \multicolumn{2}{|c|}{ Total } & 119.082 & 114 & & & \\
\hline
\end{tabular}

a. Dependent Variable : LN_NilaiPerusahaan

b. Predictors :

(Constant),OpiniGoingConcern,LN_StrukturModal,LN_UkuranPerusahaan,LN_Profitabi litas,LN_Likuiditas

Secara simultan model regresi I ukuran perusahaan, likuiditas (current ratio), profitabilitas (ROA), struktur modal (debt ratio) dam opini audit going concern mempengaruhi nilai perusahaannya manufaktur sektor consumer goods untuk periode 2015-2019 yang dapat dilihat dari besarnya F hitung 19,860 > 2,30.

\section{Hasil Uji Koefisien Determinasi}

Tabel 4.2.3 Hasil Uji Adjusted R Square Model Summary

\begin{tabular}{|l|l|r|r|r|}
\hline Model & R & R Square & $\begin{array}{c}\text { Adjusted R } \\
\text { Square }\end{array}$ & $\begin{array}{c}\text { Std, Error of } \\
\text { The Estimate }\end{array}$ \\
\hline 1 & $.690^{\mathrm{a}}$ & .477 & .453 & .75610 \\
\hline
\end{tabular}

a. Predictors :

(Constant),OpiniGoingConcern,LN_StrukturModal,LN_UkuranPerusahaan,LN_Profitabi litas,LN_Likuiditas

Besarnya variasi pengaruh kelima variabel terhadap nilai perusahaan yang ditunjukkan pada kolom adjusted $r$ square yaitu 0,453 atau 45,3\% yang mana selebihnya 54,7\% dijelaskan oleh faktor lainnya.

\section{Model Regresi II \\ Hasil Uji Wald (Parsial)}

Tabel 4.5.1 Hasil Uji Wald

\begin{tabular}{|l|l|l|l|l|l|l|}
\hline & & & & & & \\
& B & S.E. & Wald & df & Sig. & $\operatorname{Exp}(\mathrm{B})$ \\
\hline
\end{tabular}


Owner: Riset \& Jurnal Akuntansi

e-ISSN : 2548-9224 |p-ISSN : 2548-7507

Volume 5 Nomor 2, Agustus 2021

DOI : https://doi.org/10.33395/owner.v5i2.477

\begin{tabular}{|c|r|r|r|r|l|l|}
\hline Step $1^{\text {a }}$ UkuranPerusahaan & -.029 & .028 & 1.114 & 1 & .291 & .971 \\
\hline Likuiditas & .770 & .264 & 8.539 & 1 & .003 & 2.160 \\
\hline Profitabilitas & -.869 & 1.835 & .224 & 1 & .636 & .419 \\
\hline StrukturModal & 6.732 & 2.382 & 7.989 & 1 & .005 & 838.993 \\
\hline Constant & $-4,539$ & 1.591 & 8.137 & 1 &, 004 & .011 \\
\hline
\end{tabular}

Variables in the Equation

a. Variable(s) entered on step 1 : UkuranPerusahaan,Likuiditas,Profitabilitas,StrukturModal

Uji ini dilakukan dengan melihat nilai signifikansinya variabel dimana ukuran perusahaan dan profitabilitas memperlihatkan angka signifikansi yang lebih tinggi dari 0.05 sedangkan pada likuiditas dan struktur modal memperlihatkan angka signifikan di bawah 0,05. Angka ini memberi makna bahwa secara parsial yang mempengaruhi opini audit going concernnya sektor consumer goods adalah hanya likuiditas dan struktur modal sedangkan ukuran perusahaan dan profitabilitas tidak memberi pengaruh apa-apa terhadap pemberian opini audit going concernya.

\section{Hasil Uji Secara Simultan (Omnibus Test)}

Tabel 4.5.1 Hasil Uji Omnibus Test

\begin{tabular}{|ll|l|l|l|}
\hline & & Chi-square & Df & Sig. \\
\hline Step 1 & Step & 13.817 & 4 & .008 \\
\hline & Block & 13.817 & 4 & .008 \\
\hline & Model & 13.817 & 4 & .008 \\
\hline
\end{tabular}

Lantaran Chi square hasil perhitungan SPSS yaitu 13,817 yang lebih besar dari chi square tabelnya yaitu 9,48773 serta signifikan yang di bawah 0.05 maka secara simultan keempat variabel yaitu ukuran perusahaan, likuiditas, profitabilitas dan struktur modal mempengaruhi pemberian opini audit going concern secara bersamaan.

\section{Hasil Uji Koefisien Determinasi (Nagelkerke's R square)}

Tabel 4.5.2 Hasil Uji Nagelkerke's R square

Model Summary

\begin{tabular}{|l|c|c|c|}
\hline Step & $\begin{array}{c}-2 \text { Log } \\
\text { Likelihood }\end{array}$ & $\begin{array}{c}\text { Cox \& Snell R } \\
\text { Square }\end{array}$ & $\begin{array}{c}\text { Nagelkerke R } \\
\text { Square }\end{array}$ \\
\hline 1 & $120.233^{\mathrm{a}}$ & .113 & .164 \\
\hline
\end{tabular}

a. Estimation terminated at iteration number 5 because parameter estimates changed by less than .001

Besarnya pengaruh ukuran perusahaan, likuiditas, profitabilitas dan struktur modal pada pemberian opini audit going concernnya yaitu $16,4 \%$.

Hasil Uji Path Analysis

\begin{tabular}{|l|l|l|l|l|}
\hline & $\begin{array}{l}\text { Pengaruh } \\
\text { langsung }\end{array}$ & $\begin{array}{l}\text { Pengaruh } \\
\text { tidak } \\
\text { langsung }\end{array}$ & $\begin{array}{l}\text { Total } \\
\text { pengaruh }\end{array}$ & Kesimpulan \\
\hline
\end{tabular}




\begin{tabular}{|c|c|c|c|c|}
\hline $\begin{array}{l}\text { Ukuran Perusahaan } \\
\text { melalui Opini Audit } \\
\text { Going Concern } \\
\text { terhadap Nilai } \\
\text { Perusahaan }\end{array}$ & $-0,080$ & $\begin{array}{l}-0,029 \times- \\
0,081= \\
0,002349\end{array}$ & $\begin{array}{l}-0,080+ \\
0,002349= \\
-0,0777\end{array}$ & $\begin{array}{l}\text { secara tidak langsung } \\
\text { ukuran perusahaan melalui } \\
\text { opini audit going concern } \\
\text { mempunyai pengaruh } \\
\text { terhadap nilai perusahaan }\end{array}$ \\
\hline $\begin{array}{l}\text { Likuiditas melalui } \\
\text { Opini Audit Going } \\
\text { Concern terhadap } \\
\text { Nilai Perusahaan }\end{array}$ & $-0,107$ & $\begin{array}{l}0,770 x- \\
0,081=- \\
0,06237\end{array}$ & $\begin{array}{l}-0,107+- \\
0,06237=- \\
0,1694\end{array}$ & $\begin{array}{l}\text { secara tidak langsung } \\
\text { likuiditas melalui opini } \\
\text { audit going concern } \\
\text { mempunyai pengaruh } \\
\text { terhadap nilai perusahaan }\end{array}$ \\
\hline $\begin{array}{l}\text { Profitabilitas melalui } \\
\text { Opini Audit Going } \\
\text { Concern terhadap } \\
\text { Nilai Perusahaan }\end{array}$ & 0,697 & $\begin{array}{l}-0,869 x- \\
0,081= \\
0,070389\end{array}$ & $\begin{array}{l}0,697+ \\
0,070389= \\
0,7674\end{array}$ & $\begin{array}{l}\text { secara tidak langsung } \\
\text { profitabilitas melalui opini } \\
\text { audit going concern tidak } \\
\text { mempunyai pengaruh } \\
\text { terhadap nilai perusahaan }\end{array}$ \\
\hline $\begin{array}{l}\text { Pengaruh Struktur } \\
\text { Modal melalui Opini } \\
\text { Audit Going Concern } \\
\text { terhadap Nilai } \\
\text { Perusahaan }\end{array}$ & 0,168 & $\begin{array}{l}6,732 \times- \\
0,081=- \\
0,54529\end{array}$ & $\begin{array}{l}0,168+- \\
0,54529=- \\
0,3773\end{array}$ & $\begin{array}{l}\text { secara tidak langsung } \\
\text { struktur modal melalui } \\
\text { opini audit going concern } \\
\text { tidak mempunyai pengaruh } \\
\text { terhadap nilai perusahaan }\end{array}$ \\
\hline
\end{tabular}

\section{PEMBAHASAN \\ Pengaruh Ukuran Perusahaan terhadap Nilai Perusahaan}

Hasil yang didapat yaitu ukuran perusahaan tidak berpengaruh terhadap nilai perusahaan. Sejalan juga dengan hasil yang didapat oleh (Isnaini et al., 2020) yaitu ukuran perusahaan tidak memberi pengaruh terhadap nilai perusahaan. Dengan demikian besar kecilnya perusahaan tidak dapat dijadikan patokan untuk menilai perusahaan, dikarenakan perusahaan besar belum tentu memiliki kinerja yang lebih baik daripada perusahaan kecil, dengan kata lain banyak perusahaan kecil namun penjualannya dapat berkembang dengan pesat sehingga nilai perusahaannya meningkat, sebaliknya ada perusahaan besar karena gagal dalam operasionalnya sehingga nilai perusahaannya menurun.

\section{Pengaruh Likuiditas terhadap Nilai Perusahaan}

Hasil yang didapat yaitu likuiditas tidak berpengaruh terhadap nilai perusahaan. Sejalan juga dengan hasil yang didapat oleh (Nauli et al., 2021) yaitu likuiditas tidak mempengaruhi nilai perusahaan. Hal ini dikarenakan perusahaan yang memiliki tingkat likuiditas yang tinggi belum tentu memiliki tingkat likuid yang baik, hal ini dikarenakan semakin tinggi pos aktiva lancar menunjukkan banyaknya dana yang menganggur yang tidak dimanfaatkan dengan baik sehingga likuiditas tidak dapat dijadikan sebagai indikator dalam menentukan nilai perusahaan.

\section{Pengaruh Profitabilitas terhadap Nilai Perusahaan}

Hasil yang didapat yaitu profitabilitas berpengaruh positif terhadap nilai perusahaan. Sejalan dengan hasil yang didapat oleh (Yanti \& Damayanti, 2019) yaitu profitabilitas memiliki pengaruh positif dan signifikan terhadap nilai perusahaan. Hasil penelitian ini menunjukkan tidak adanya pengaruh profitabilitas (ROA) yang digunakan auditor dalam memberikan opini audit is ongoing. Nilai ROA dapat di jelaskan sebagai persentase laba yang dihasilkan dalam pemanfaatan aset perusahaan. Nilai ROA yang rendah, bukan berarti buruk. Jika perusahaan melakukan investasi yang menyebabkan nilai ROA yang rendah, auditor perlu menilai bagaimana tindakan manajemen risiko perusahaan dalam menilai dan menangani sebab dan akibat dari ketidakpastian tersebut. Jika rencana manajemen cukup pengungkapan dalam mengurangi risiko pada awal proyek, maka perusahaan masih bisa dalam mengembangkan potensi asetnya guna menghasilkan laba.

\section{Pengaruh Struktur Modal terhadap Nilai Perusahaan}

Hasil yang didapat yaitu struktur modal tidak berpengaruh terhadap nilai perusahaan. Juga sejalan dengan hasil yang didapat oleh (Uli et al., 2020) yaitu struktur modal tidak mempengaruhi 
nilai perusahaan. Hal ini dikarenakan dalam mendukung kegiatan aktivitas operasonalnya Consumer Goods Industry harus menggunakan hutang yang cukup tinggi misalnya pembelian mesin produksi yang lebih canggih sehingga dapat meningkatkan hasil produksi. Sejauh perusahaan dapat memanfaatkan penggunaan hutangnya dengan baik maka penggunaan hutang yang meningkat akan dinilai wajar oleh pasar/investor.

\section{Pengaruh Opini Audit Going Concern terhadap Nilai Perusahaan}

Hasil yang didapat yaitu opini audit going concern tidak berpengaruh terhadap nilai perusahaan dan juga didukung oleh hasil yang didapat (Diantari \& Suryanawa, 2019) yaitu opini audit tidak berpengaruh terhadap nilai perusahaan. Hal ini dikarenakan pada perusahaan Consumer Goods Industry jarang mendapat opini audit going concern, salah satu yaitu sektor ini sangat diminati oleh investor sehingga perusahaan cenderung akan transparan dalam mengungkapkan data keuangannya kepada auditor.

\section{Pengaruh Ukuran Perusahaan terhadap Opini Audit Going Concern}

Hasil yang didapat yaitu ukuran perusahaan tidak berpengaruh terhadap opini audit going concern. Sejalan dengan hasil yang didapat oleh (Rahmawati et al., 2018) yaitu ukuran perusahaan tidak berpengaruh terhadap opini audit going concern. Hal ini menunjukkan besar kecilnya perusahaan tidak dapat menjadi penentu auditor dalam memberikan opini audit going concern, dikarenakan perusahaan juga tidak ingin mendapat opini audit going concern sehingga perusahaan baik besar maupun kecil akan berusaha untuk mengontrol kinerja keuangannya sebaik mungkin.

\section{Pengaruh Likuiditas terhadap Opini Audit Going Concern}

Hasil yang didapat yaitu likuiditas berpengaruh positif signifikan terhadap opini audit going concern. Hal ini sejalan dengan penelitian (Andini et al., 2021) yang menunjukkan likuiditas berpengaruh terhadap opini audit going concern. Likuiditas menunjukkan kemampuan perusahaan dalam melunasi kewajiban lancarnya jika perusahaan mampu melunasi kewajiban tersebut tepat waktu berarti perusahaan dapat dikatakan telah berhasil dalam mengelola aktivitasnya.

\section{Pengaruh Profitabilitas terhadap Opini Audit Going Concern}

Hasil yang didapat yaitu profitabilitas tidak berpengaruh terhadap opini audit going concern. Sejalan dengan hasil didapat oleh (Sari, 2020) profitabilitas tidak berpengaruh terhadap opini audit going concern. hal ini menunjukkan bahwa profitabilitas tidak dapat dijadikan penentu dalam pemberian opini audit going concern dikarenakan meskipun perusahaan mampu menghasilkan profit namun yang dipertanyakan adalah apakah perusahaan mampu memanfaatkan / mengelola perusahaan dengan baik dengan berinvestasi pada peluang investasi yang tepat.

\section{Pengaruh Struktur Modal terhadap Opini Audit Going Concern}

Hasil yang didapat yaitu struktur modal berpengaruh positif signifikan terhadap opini audit going concern. Sejalan dengan penelitian (Simanjuntak, et al., 2020) yang menunjukkan DER juga berpengaruh positif terhadap opini audit going concern. Hal ini berarti jika perusahaan menambah hutang, maka kemungkinan perusahaan akan mendapat opini audit going concern, karena dalam kebutuhan penambahan hutangnya sering kali dapat mempengaruhi kinerja keuangan lainnya.

\section{KESIMPULAN}

Berdasarkan hasil pengolahan data yang telah peneliti lakukan, maka simpulan dari hasil penelitian ini Hanya profitabilitas yang berpengaruh terhadap nilai perusahaan sedangkan ukuran perusahaan, likuiditas, struktur modal dan opini audit going concern tidak berpengaruh terhadap nilai perusahaan Hanya likuiditas dan struktur modal yang berpengaruh terhadap opini audit going concern sedangkan ukuran perusahaan dan profitabilitas tidak berpengaruh terhadap opini audit going concern.Secara tidak langsung ukuran perusahaan dan likuiditas melalui opini audit going concern mempunyai pengaruh terhadap nilai perusahaan sedangkan secara tidak langsung 
profitabilitas dan struktur modal melalui opini audit going concern tidak mempunyai pengaruh terhadap nilai perusahaan

\section{REFERENSI}

Analisa, Y. (2011). Pengaruh Ukuran Perusahaan, Leverage, Profitabilitas dan Kebijakan Dividen Terhadap Nilai Perusahaan (studi pada perusahaan manufaktur yang terdaftar di Bursa Efek Indonesia). Fakultas Ekonomi Universitas Diponegoro.

Andini,N.,Yani, M.,\& Asmeri, R. (2021). Analisis Pengaruh Profitabilitas, Cash Flow, dan Kebijakan Manajemen terhadap Opini Audit Going Concern pada Perusahaan Manufaktur yang Terdaftar di Bursa Efek Indonesia. Jurnal Indovisi.

Alichia, Y. P. (2013). Pengaruh Ukuran Perusahaan , Pertumbuhan Perusahaan , Dan Opini Audit Tahun Sebelumnya Terhadap Opini Audit Going Concern(Studi Empiris Perusahaan Manufaktur yang terdaftar pada Bursa Efek Indonesia). Universitas Negeri Padang.

Dewayanto, T. (2011). Analisis faktor-faktor yang mempengaruhi penerimaan opini audit going concern pada perusahaan manufaktur yang terdaftar di bursa efek indonesia. Jurnal Bisnis Dan Akuntansi.

Diantari, K. I., \& Suryanawa, I. K. (2019). Pengaruh Opini Auditor dan Pertumbuhan Penjualan Perusahaan pada Nilai Perusahaan. E-Jurnal Akuntansi. https://doi.org/10.24843/eja.2019.v26.i02.p10

Jimenez. (2015). Pengaruh Debt To Equity Ratio (DER),Debt To Total Asset (DTA), Dividen Tunai, dan Ukuran Perusahaan Terhadap Nilai Perusahaan. Ekp.

Indriyani, E. (2017). Pengaruh Ukuran Perusahaan dan Profitabilitas Terhadap Nilai Perusahaan Akuntabilitas. https://doi.org/10.15408/akt.v10i2.4649

Isnaini, K. M. L., \& Widyawati, D. (2020). Pengaruh Ukuran Perusahaan, Profitabilitas, dan Pertumbuhan Perusahaan terhadap Struktur Modal. Jurnal IIlmu Dan Riset Akuntansi.

Khairunnisa, T., Taufik, T., \& Thamrin, K. M. H. (2019). Pengaruh Debt To Equity Ratio, Return On Assets, Assets Growth, Current Ratio, dan Total Assets Turnover Terhadap Nilai Perusahaan pada Perusahaan Sektor Makanan dan Minuman yang Terdaftar di Bursa Efek Indonesia. JEMBATAN.https://doi.org/10.29259/jmbt.v16i1.9253

Minerva, L., Sumeisey, V. S., Stefani, S., Wijaya, S., \& Lim, C. A. (2020). Pengaruh Kualitas Audit, Debt Ratio, Ukuran Perusahaan dan Audit Lag terhadap Opini Audit Going Concern. Owner. https://doi.org/10.33395/owner.v4i1.180

Mardiyati, U. (2012). Pengaruh Kebijakan Dividen, Kebijakan Hutang dan Profitabilitas Terhadap Nilai Perusahaan Terdaftar Yang Terdaftar di Bursa Efek Indonesia Efek Indonesia (BEI) Periode 2005-2010. Jurnal Riset Manajemen Sains Indonesia (JRMSI).

Martha, L., Sogiroh, N. U., Magdalena, M., Susanti, F., \& Syafitri, Y. (2018). Profitabilitas Dan Kebijakan Dividen Terhadap Nilai Perusahaan. Jurnal Benefita. https://doi.org/10.22216/jbe.v3i2.3493

Nauli, A., Halim, C., \& Sonia. (2021). Pengaruh Likuiditas,Profitabilitas,Struktur Modal,Ukuran Perusahaan Dan Kebijakan Dividen Terhadap Nilai Perusahaan Perusahaan Manufaktur Yang Terdaftar Di Bursa Efek Indonesia. Journal of Economic, Business and Accounting.

Nugroho, L., Nurrohmah, S., \& Anasta, L. (2018). Faktor-faktor Yang Mempengaruhi Opini Audit Going Concern. Jurnal SIKAP (Sistem Informasi, Keuangan, Auditing Dan Perpajakan). https://doi.org/10.32897/sikap.v2i2.79

Rahman, M. A., \& Ahmad, H. (2018). Pengaruh Likuiditas, Profitabilitas, dan Solvabilitas Terhadap Opini Audit Going Concern. Jurnal Akuntansi.

Rahmawati, D., Dwi Wahyuningsih, E., \& Setiawati, I. (2019). Pengaruh Likuiditas, Ukuran Perusahaan, Pertumbuhan Perusahaan, dan Opini Audit Tahun Sebelumnya terhadap Opini Audit Going Concern (Studi Empiris Perusahaan Manufaktur yang Terdaftar di Bursa Efek Indonesia). MAKSIMUM. https://doi.org/10.26714/mki.8.2.2018.67-76

Rakatenda, G. N., \& Putra, I. W. (2016). Opin Audit Going Concern dan Faktor - Faktor yang Mempegaruhinya. E-Jurnal Akuntansi Universitas Udayana. 
Ristanti, V. (2015). Pengaruh Likuiditas dan Efisiensi Modal Kerja terhadap Profotabilitas Perusahaan (Studi pada Perusahaan Food and Beverages yang Terdaftar di BEI tahun 20112013). Jurnal Administrasi Bisnis S1 Universitas Brawijaya.

Sari, D. I. (2020). Pengaruh Quick Ratio, Total Asset Turnover dan Return on Investment Terhadap Harga Saham. BALANCE : JURNAL AKUNTANSI DAN BISNIS. https://doi.org/10.32502/jab.v5i2.2876

Simanjuntak, C. T., Hutasoit, S. R. S., Simamora, E., \& Hayati, K. (2020). Pengaruh Rasio Keuangan dan Faktor Non Keuangan Terhadap Penerimaan Opini Audit Going Concern. EJurnal Ekonomi Dan Bisnis Universitas Udayana. https://doi.org/10.24843/eeb.2020.v09.i08.p03

Sitorus, T., \& Elinarty, S. (2017). The Influence of Liquidity and Profitability toward the growth of Stock price mediated by the Dividen Paid out (Case in banks listed in Indonesia Stock Exchange). Journal of Economics, Business \& Accountancy Ventura. https://doi.org/10.14414/jebav.v19i3.582

Suryandani, A. (2018). Pengaruh Pertumbuhan Perusahaan,Ukuran Perusahaan dan Keputusan Investasi terhadap Nilai Perusahaan pada Perusahaan Sektor Property dan Real Estate Di BEI.BMAJ:Business Management Analysis Journal. https://doi.org/10.24176/bmaj.v1i1.2682

Sudana, I. M. (2011). Manajemen Keuangan Perusahaan Teori \& Praktik. In Erlangga.

Sutrisno, S. (2013). Manajemen Keuangan Teori Konsep dan Aplikasi. In Manajemen Keuangan Teori Konsep dan Aplikasi.

Uli, R., Ichwanudin, W., \& Suryani, E. (2020). Pengaruh Likuiditas Terhadap Nilai Perusahaan Melalui Struktur Modal Dan Profitabilitas. Tirtayasa EKONOMIKA.

Putra, A., \& Lestari, P. (2016). Pengaruhb Kebijakan Dividen, Likuiditas, Profitabilitas dan Ukuran Perusahaan terhadap Nilai Perusahaan. None.

Wardhani, R. S. (2013). Pengaruh CSR Disclosure terhadap Nilai Perusahaan dengan Kinerja Keuangan sebagai Variabel Intervening (Studi Kasus Perusahaan Manufaktur yang Terdaftar di BEI). Jurnal Ekonomi Akuntansi Manajemen ISSN: 1412-5366.

Widyantari, A. A. A. P. (2011). Opini Audit Going Concern Dan Faktor-faktor yang Mempengaruhi: Studi pada Perusahaan Manufaktur di Bursa Efek Indonesia. Universitas Udayana.

Yanti, I. G. A. D. N., \& Darmayanti, N. P. A. (2019). Pengaruh Profitabilitas, Ukuran Perusahaan, Struktur Modal, dan Likuiditas terhadao Nilai Perusahaan Makanan dan Minuman. E-Jurnal Manajemen Universitas Udayana. https://doi.org/10.24843/ejmunud.2019.v08.i04.p15 